\title{
Porous titanium alloy/hydroxyapatite composite using powder compaction route
}

\author{
Amir Arifin ${ }^{1, *}$, Abu Bakar Sulong ${ }^{2}$, Lee Choy Fun ${ }^{2}$, Gunawan $^{1}$ and Irsyadi Yani ${ }^{1}$ \\ ${ }^{1}$ Department of Mechanical Engineering, Sriwijaya University, \\ 30662 Indralaya, Sumatera Selatan, Indonesia \\ *Email: amir@unsri.ac.id \\ ${ }^{2}$ Department of Mechanical and Material Engineering, Universiti Kebangsaan \\ Malaysia, 43600 Bangi, Selangor, Malaysia
}

\begin{abstract}
Titanium alloys (Ti6Al4V) and hydroxyapatite (HA) are widely used as implant materials. Ti6Al4V has good mechanical properties and corrosion resistance, whereas HA has excellent biocompatibility but its mechanical properties are weak. The combination of properties between Ti6Al4V and HA is expected to produce a superior material for bio-implants. The aim of this work is to analyse the fabricating porous Ti6Al4V/HA composite through powder compaction with the application of two types of space holders. Sodium chloride $(\mathrm{NaCl})$ and polymethyl methacrylate (PMMA) were selected as the space holder agents. Space holders were removed by solvent debinding $(\mathrm{NaCl})$ and thermal debinding (PMMA). Sintering was performed in a furnace at $1200{ }^{\circ} \mathrm{C}$ for $1.5 \mathrm{~h}$. The Archimedes method was carried out to obtain the porosity of the sintered body. Samples where $\mathrm{NaCl}$ was used exhibited higher porosity than the samples where for PMMA was used. The high porosity achieved among the successfully sintered samples was $43.9 \%$. Interconnected porous was clearly observed on the sintered composites with a successfully generated size range of $2 \mu \mathrm{m}$ to $25 \mu \mathrm{m}$.
\end{abstract}

Keywords: titanium-hydroxyapatite foam; space holder method, powder metallurgy.

\section{INTRODUCTION}

Porous structure is one of the requirements that must be met in an implant. Implants must have the biocompatibility properties of the body. Beside that, the mechanical properties of the implant must be in accordance with the bone mechanical properties such as the Young's modulus and hardness [1]. Today, implants not only have to approach the mechanical properties of bone, but also should be able to facilitate the growth of cells during healing [2]. Porous structures on the implant are expected to facilitate the blood flow that supplies nutrients to the cell tissues. In addition, the existence of a porous structure is able to reduce the Young's modulus of metal implants so as to approach the Young's modulus of bones [3, 4]. The classic issue in the fabrication of Ti6Al4V / HA composites through Powder Metallurgy method is the two substances having different properties in terms of physical and chemical properties. Titanium at high temperatures tends to be oxidised and will react with other substances [5], while HA will become unstable at high temperatures so that it can decompose into other phases. The presence of titanium ion during the sintering process will speed up the HA decomposition process and will affect the physical and mechanical properties. Furthermore, the difference in thermal coefficients between the two materials will induce cracking during the sintering process 
[6]. This is often the case in composites that use more than one type of substance with different heat coefficients. In addition to the composition problems above, the difference in shapes and sizes of the two substances will also affect the arrangement of the powder and the physical and mechanical properties of the composites [7].

The selection of suitable implant materials is a critical step in designing medical implants. Many biomaterials such as Co-Cr alloy, stainless steel, and titanium alloy are available. Titanium alloy is one of the potential candidates usually chosen by researchers because it is characterised by excellent corrosion resistance, bioinertness, and high strength-to-weight ratio [8-11]. Another important property of titanium alloy is that it has a lower Young's modulus than other biomaterials (110 GPa)[12]. The bone has a Young's modulus of $10 \mathrm{GPa}$ to $30 \mathrm{GPa}$ and a hardness that ranges from $0.2 \mathrm{GPa}$ to $0.7 \mathrm{GPa}$ [13, 14]. In the category of ceramics, hydroxyapatite (HA) is a considerably favourable option because it has a chemical structure similar to that of the human bones [15]. HA more significantly promotes cell growth than does titanium alloy. Nevertheless, HA has poor mechanical properties. A well-known issue in designing metal implants is that metal has a higher Young's modulus than bone, resulting in non-uniform stress transfer between bones and implant materials. The Young's modulus of materials proportionally decreases with increasing porosity [16]. The other advantage of porous structures, especially interconnected types, is that they facilitate blood circulation, which carries nutrient to cells [17-19]. Composite is a combination of one or more materials in which the combination of the material will produce the desired physical and mechanical properties [20-26]. The combination of titanium alloy, HA, and porous structures is expected to solve several weaknesses in medical implant applications [27]. Various studies have been conducted to combine titanium and HA. Zhuravleva et al. [28] proposed a method for combining Ti40Nb and HA by compaction and HA coating. The porous structure of $\mathrm{Ti} 40 \mathrm{Nb}$ was prepared by the compaction method with $\mathrm{NaCl}$ or $\mathrm{Mg}$ as the space holder. For nanostructures, Niespodziana et al. [29] successfully produced microporous TI/HA with a mechanical alloying method. The infiltration method has also successfully produced Ti/HA composite with a porosity range of $24 \%$ to $34 \%$ [30]. The main objective of this work is to analyse fabricating porous Ti6Al4V/HA composite with the application of space holder materials (i.e., Sodium chloride $(\mathrm{NaCl})$ and polymethyl methacrylate (PMMA)) through the powder compaction method.

\section{METHODS AND MATERIALS}

\section{Experimental Setup}

Titanium powder (Ti6Al4V), with a density and melting point of $4.43 \mathrm{~g} / \mathrm{cm}^{3}$ and 1604 ${ }^{\circ} \mathrm{C}$, respectively, was obtained from Vistec Technology Malaysia (Figure 1(a)). HA powder with a density of $3.132 \mathrm{~g} / \mathrm{cm}^{3}$ (Figure 1(b)) was supplied by Sigma Aldrich. $\mathrm{NaCl}$ and PMMA were selected as the space holders in this study. $\mathrm{NaCl}$ with a density and melting point of $2.165 \mathrm{~g} / \mathrm{cm}^{3}$ and $801{ }^{\circ} \mathrm{C}$, respectively, was supplied by Sigma Aldrich. $\mathrm{NaCl}$ was chosen as a space holder because it is easily dissolved in water, inexpensive, and nontoxic [31]. PMMA is easy to decompose and evaporates at low temperatures. PMMA with a density and melting point of $1.18 \mathrm{~g} / \mathrm{cm}^{3}, 160^{\circ} \mathrm{C}$, respectively, was supplied by Alfa Ceaser. Tables 1 and 2 show the powder and space holder composition. Ti6Al4V and HA powder were combined using a ball milling machine (Pulversetta 6) at a milling speed of $200 \mathrm{rpm}$ for $3 \mathrm{~h}$. 


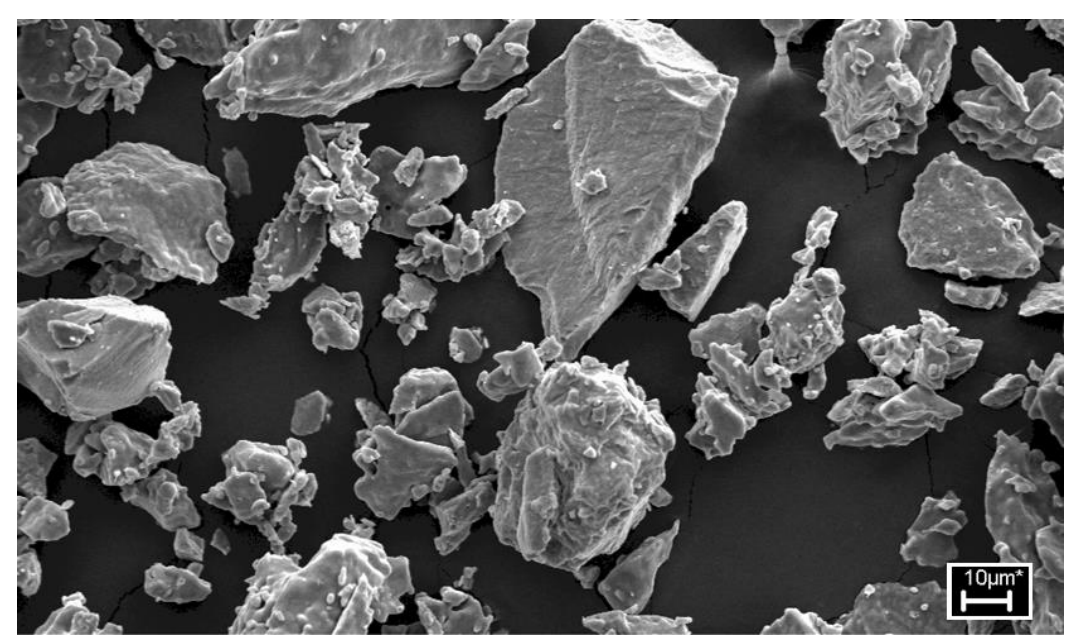

(a)

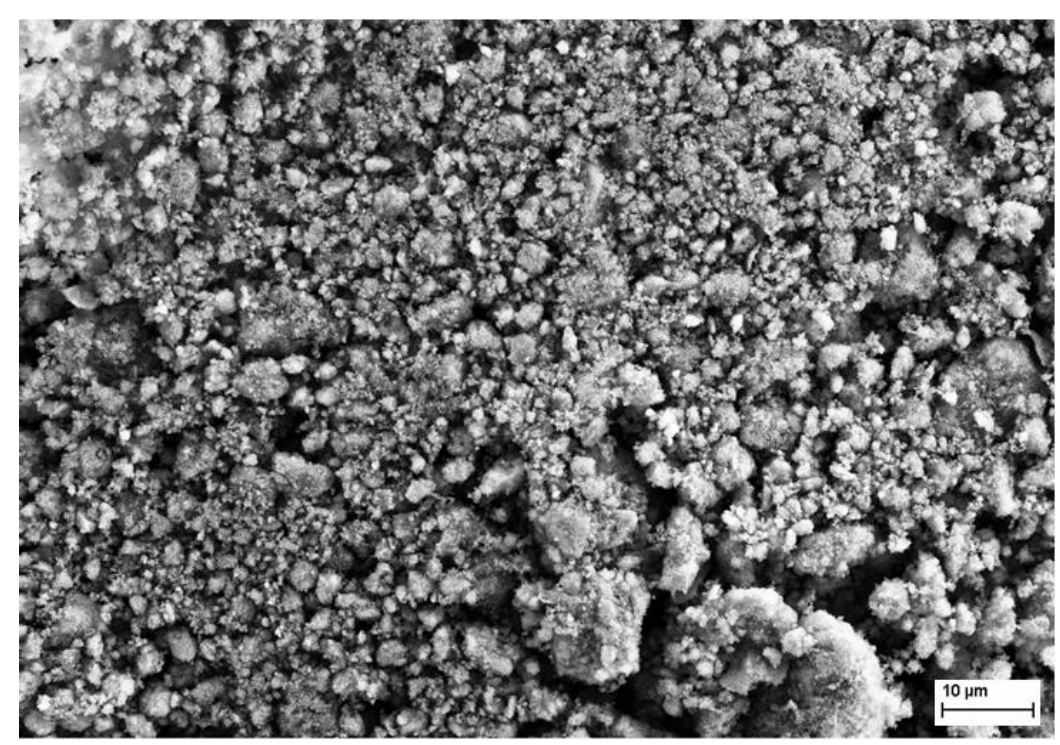

(b)

Figure 1. Scanning electron microscopy results for Ti6Al4V (a) and HA (b).

Table 1. Mixing ratio for titanium and HA powder.

\begin{tabular}{ccc}
\hline Mixture & Ti6Al4V $(\% \mathrm{wt})$ & HA $(\% \mathrm{wt})$ \\
\hline I & 70 & 30 \\
II & 30 & 70 \\
\hline
\end{tabular}

Table 2. Mixing ratio for Ti6Al4V/HA powder and space holder.

\begin{tabular}{ccc}
\hline Sample & $\begin{array}{c}\text { Ti6Al4V/HA (\%wt) } \\
\text { Powder }\end{array}$ & Space Holder (\%wt) \\
\hline $\mathrm{A}$ & $80 \%$ wt Mixture I & $20 \%$ wt PMMA \\
$\mathrm{B}$ & $80 \%$ wt Mixture II & $20 \%$ wt PMMA \\
$\mathrm{C}$ & $80 \%$ wt Mixture II & $20 \% \mathrm{wt} \mathrm{NaCl}$ \\
\hline
\end{tabular}

The powder mixture of each sample was compacted in a mold with a pressure of $200 \mathrm{MPa}$ for $10 \mathrm{~min}$. Debinding was carried out to remove the space holder in a green 
body. PMMA was removed by thermal debinding under an argon flow for $1.5 \mathrm{~h}$ at a heating rate of $5{ }^{\circ} \mathrm{C} / \mathrm{min}$. $\mathrm{NaCl}$ was soaked in distilled water for $3 \mathrm{~h}$. The sintering temperature was set at $1200{ }^{\circ} \mathrm{C}$ for $1.5 \mathrm{~h}$ and the heating rate was $10^{\circ} \mathrm{C} / \mathrm{min}$; the sintered sample was analysed. Hardness (MITAKA HVS10) and density tests were carried out in accordance with the Archimedes principle. The morphology of the surface was studied by scanning electron microscopy (SEM) and electron dispersive X-ray spectroscopy (EDX) was performed to determine the presence of elements in the sample using Hitachi S-3400N. Meanwhile, XRD test was performed using the Bruker D8 Advance XRD.

\section{RESULTS AND DISCUSSION}

\section{Debinding}

Table 3 shows the weight reduction of each sample after debinding. On sample $\mathrm{C}$ for which $\mathrm{NaCl}$ was used as the space holder, a significant weight reduction was observed. Removing the space holder by solvent debinding promoted erosion on the powder, thereby reducing the sample weight. This result was confirmed by the density and porosity tests (Table 4). Sample C had low density and high porosity. The thermal debinding results also exhibited a potential problem in debinding temperature, which affected the mechanical strength of the green component [32-35].

Table 3. Results of debinding.

\begin{tabular}{cccc}
\hline $\begin{array}{c}\text { Sample } \\
\text { Code }\end{array}$ & Space holder & $\begin{array}{c}\text { Before debinding, } \\
\text { (gram) }\end{array}$ & $\begin{array}{c}\text { After debinding, } \\
\text { (gram) }\end{array}$ \\
\hline A & 20\%wt PMMA & 3.00 & 2.87 \\
B & 20\%wt PMMA & 2.80 & 2.67 \\
C & 20\%wt NaCl & 2.70 & 2.14 \\
\hline
\end{tabular}

\section{Density and Porosity}

Table 4 shows the density and porosity sample, Ti6Al4V/HA, after sintering. Sample A with PMMA as the space holder had the highest density, affecting the main composition of titanium in the mixture. The porosity of sample A supported the findings of Torres et al. (2011). The porosity of titanium alloy (i.e., 45\%) is similar to the Young's modulus of human bones [31]. The Young's modulus of Ti/HA composite ranges from $24 \%$ to $34 \%$ [30]. The weight reduction of samples $B$ and $C$ was attributed to the large decomposition of HA, which was a dominant constituent in the mixture. Comparing samples B and C, which were similar in powder composition but different in space holder and debinding method, sample $\mathrm{C}$ had a higher porosity value (43.85\%), indicating a micro and macro porous structure.

Table 4. Density and porosity test on sintered component of porous Ti6Al4V/HA composite.

\begin{tabular}{ccc}
\hline Sample & Density $\left(\mathrm{g} / \mathrm{cm}^{3}\right)$ & Porosity $(\%)$ \\
\hline A & 3.343 & 15.15 \\
B & 2.639 & 23.06 \\
C & 1.926 & 43.85 \\
\hline
\end{tabular}




\section{Microstructure Analysis}

Sample A (70 wt\% Ti6Al4V : 30 wt\% HA: PMMA)

Figure 2 shows the analysis of pore morphology and structure properties of sample A. Binding occurred between Ti6Al4V and HA after sintering. The SEM results showed that pore size ranged from $5 \mu \mathrm{m}$ to $25 \mu \mathrm{m}$ in the interconnected structure. The morphology pore and structure results via this method were in line with the findings reported by some authors [36-38]. The osteoblast size at the entrance of the interconnected structure is $20 \mu \mathrm{m}$, as indicated by the in vitro and in vivo experiments [39]. The types of pore formation were determined by the combination of PMMA removal and morphological examination of titanium particles.

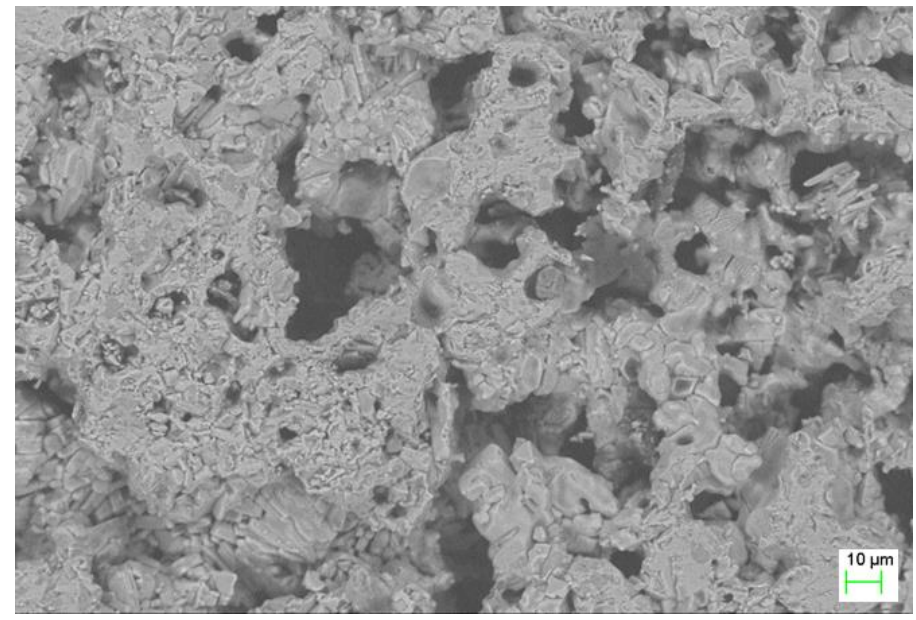

Figure 2. SEM photographs of porous Ti6Al4V/HA Composite.

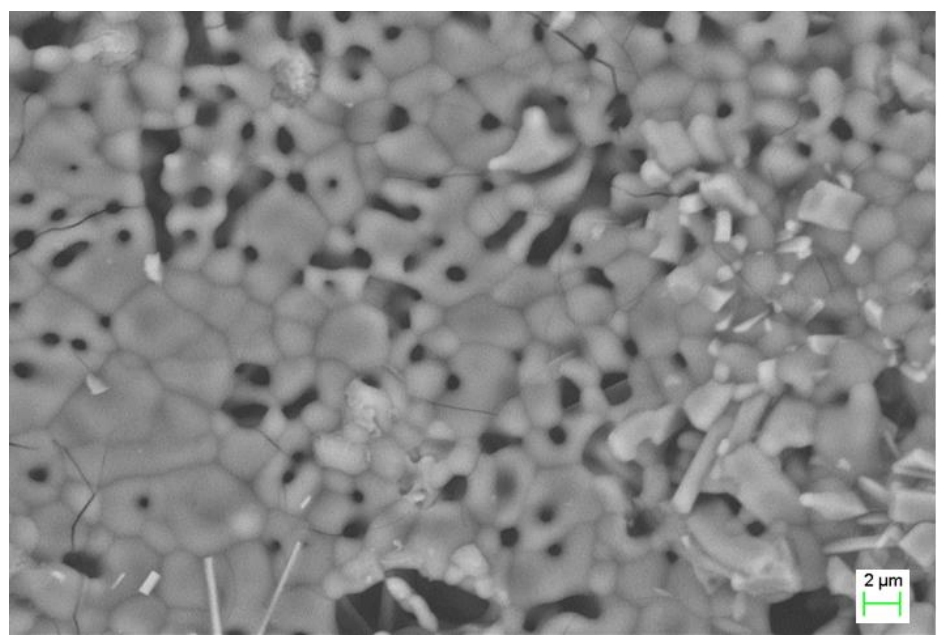

Figure 3. SEM images of porous Ti6Al4V/HA Composite.

\section{Sample B (30 wt\% Ti6Al4V : 70 wt\% HA: PMMA)}

Figure 3 shows that the pore morphology structure which comprised $30 \mathrm{wt} \%$ Ti: $70 \mathrm{wt} \%$ HA with PMMA as the space holder. SEM observations revealed that microporous finds were of a size of around $2 \mu \mathrm{m}$. Microporous formation occurred due to the higher percentage weight of the HA powder and had a finer particle size than the Ti powder. Moreover, the type of pores can be characterised as open pores. 


\section{Sample C (30 wt\% Ti6Al4V : 70 wt\% $\mathrm{HA}: \mathrm{NaCl})$}

Figure 4 shows a pore structure composed of $30 \mathrm{wt} \% \mathrm{Ti}$ and $70 \mathrm{wt} \% \mathrm{HA}$ with $\mathrm{NaCl}$ as the space holder. The pore types in Figure 4 can be categorised into two types. Small pores resulted from the space holder and large pores were caused by erosion when $\mathrm{NaCl}$ was removed by solvent debinding. The porous formation formed was interconnected porous, necessary when used as implantable material as it can facilitate cell growth. Interconnected porous facilitates blood circulation that carries nutrients for cell growth.

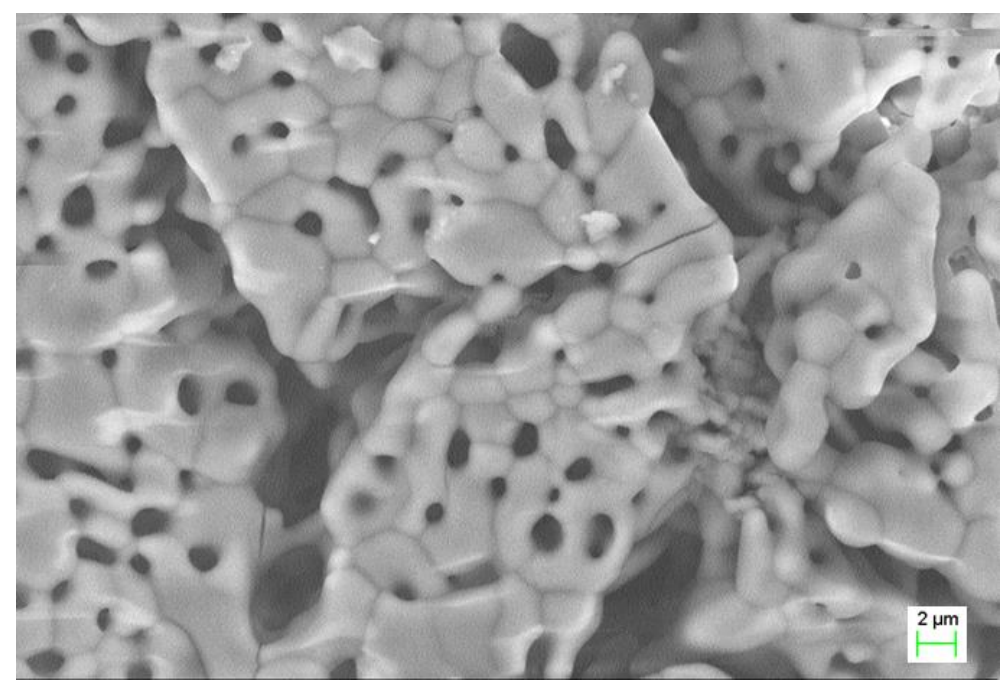

Figure 4. SEM images of porous Ti6Al4V/HA Composite.

\section{Energy-dispersive X-ray spectroscopy}

For sample A, oxygen content was highest at $38.5 \mathrm{wt} \%$. HA and PMMA powder were affected by the addition of oxygen elements. The sintering process was conducted in standard atmospheric conditions. Figure 5 shows that the percentage of oxygen in the sintered body was high.

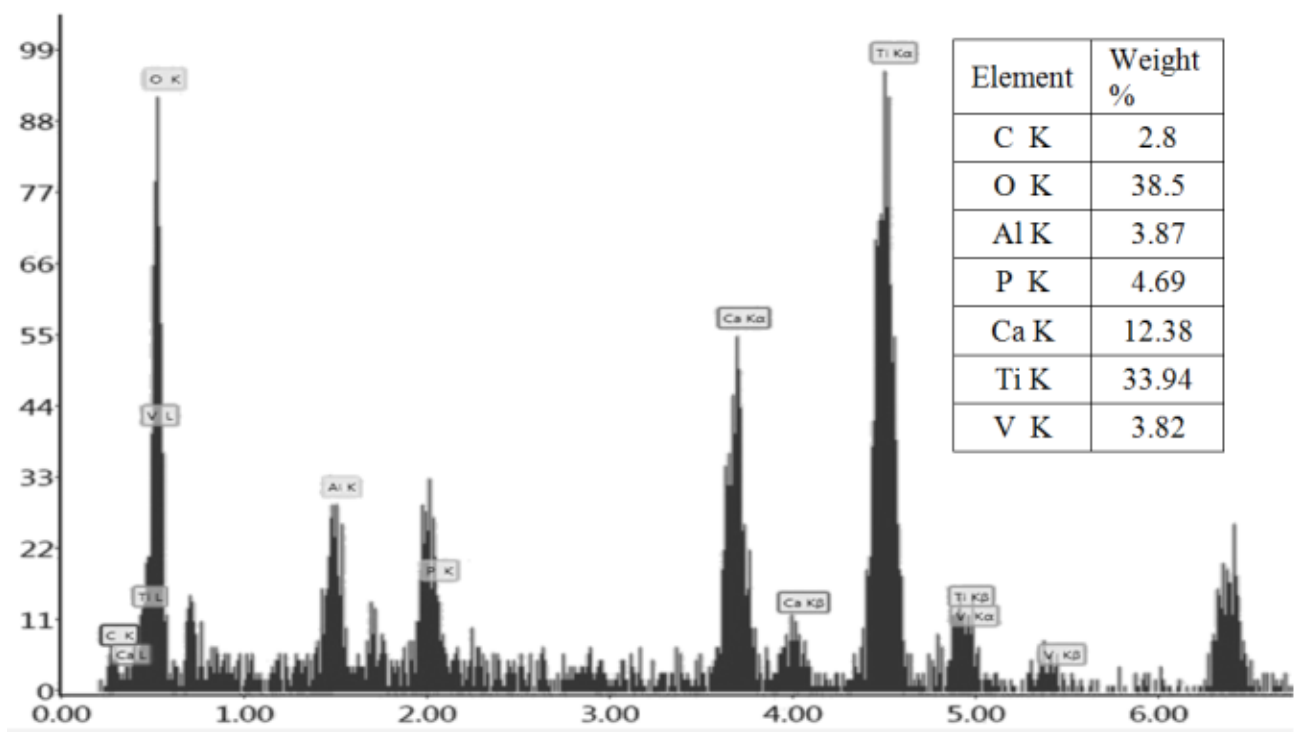

Figure 5. EDX graph for sample A (70wt\% Ti6Al4V : $30 w t \%$ HA: PMMA). 
According to the EDX graphs for sample B (Figure 6), calcium (Ca) had the highest weight percentage $(36.52 \%)$ when the ratio of HA powder to Ti was high. The oxygen percentage shown in the result was less than that of sample A $(10.46 \%)$. The EDX graph shows that PMMA had a carbon (C) composition close to $0 \%$. Therefore, the space holder was successfully removed during debinding and sintering. The oxygen level in sample B was lower than that in sample A, indicating that the oxidation level of sample $\mathrm{B}$ was lower than sample A. The presence of Ti in the compound influenced the oxidation level where titanium started oxidising at a low temperature of $450^{\circ} \mathrm{C}$ compared to $\mathrm{HA}$ which started to decompose at above the temperature of $850^{\circ} \mathrm{C}$ [40]. It is clear that the oxidation level of sample A was higher than sample B due to the high proportion of Ti in the sample.

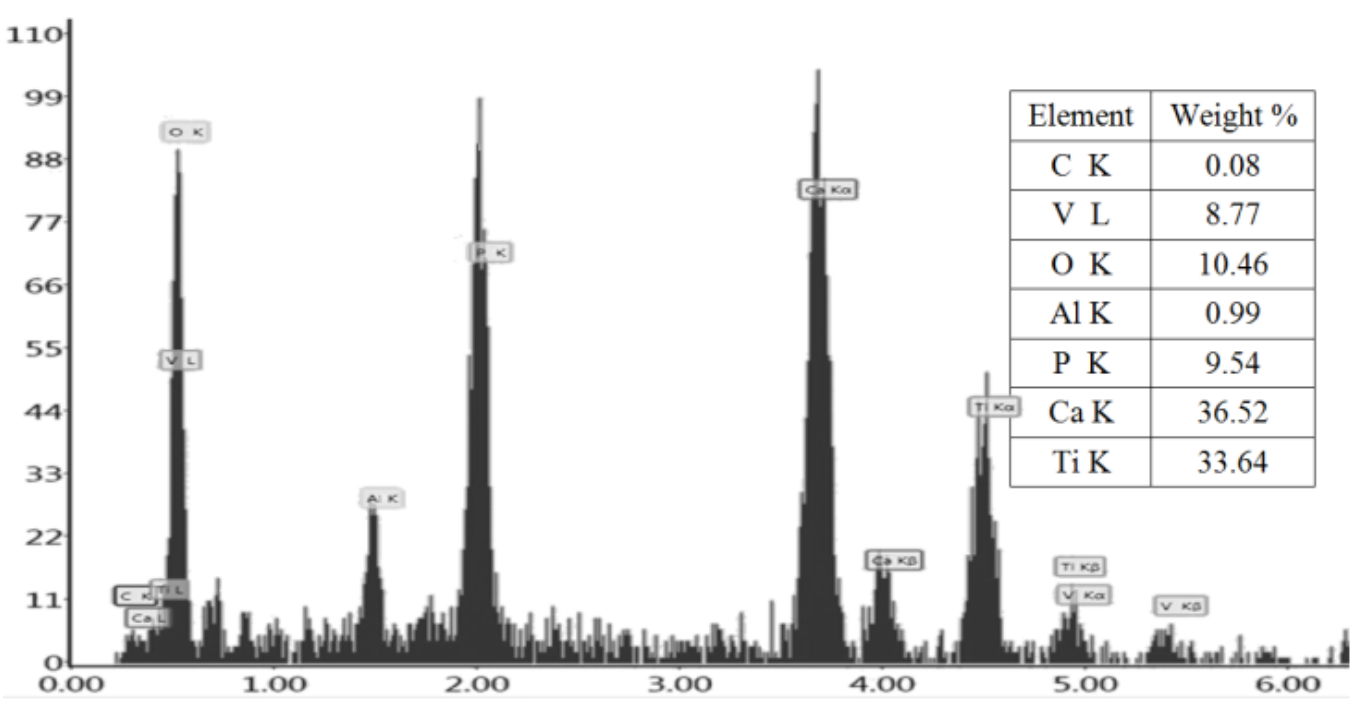

Figure 6. EDX graph for sample B (30wt\% Ti6Al4V : $70 w t \%$ HA: PMMA).

The samples were analysed before and after sintering to compare the elemental composition. Figure 7 and Table 5 show that sodium $(\mathrm{Na})$ and chloride $(\mathrm{Cl})$ remained in the samples before sintering and after debinding. By contrast, $\mathrm{Na}$ and $\mathrm{Cl}$ were removed after sintering. The oxygen percentage also increased from $36.55 \%$ to $38.6 \%$.

Table 5. EDX analysis results for sample C (before and after sintering)

\begin{tabular}{ccccc}
\hline & \multicolumn{3}{c}{ Before sintering } & After Sintering \\
Element & Weight \% & K Ratio & Weight \% & K Ratio \\
\hline $\mathrm{O}$ & 36.55 & 0.0683 & 38.6 & 0.0739 \\
$\mathrm{Na}$ & 0.69 & 0.003 & - & - \\
$\mathrm{Al}$ & 0.55 & 0.004 & 0.23 & 0.0016 \\
$\mathrm{P}$ & 18.98 & 0.1651 & 19.55 & 0.17 \\
$\mathrm{Cl}$ & 0.85 & 0.0074 & - & - \\
$\mathrm{Ca}$ & 34.37 & 0.3178 & 36.15 & 0.3316 \\
$\mathrm{Ti}$ & 8.01 & 0.0634 & 4.17 & 0.0328 \\
$\mathrm{~V}$ & - & - & 1.3 & 0.0101 \\
\hline
\end{tabular}




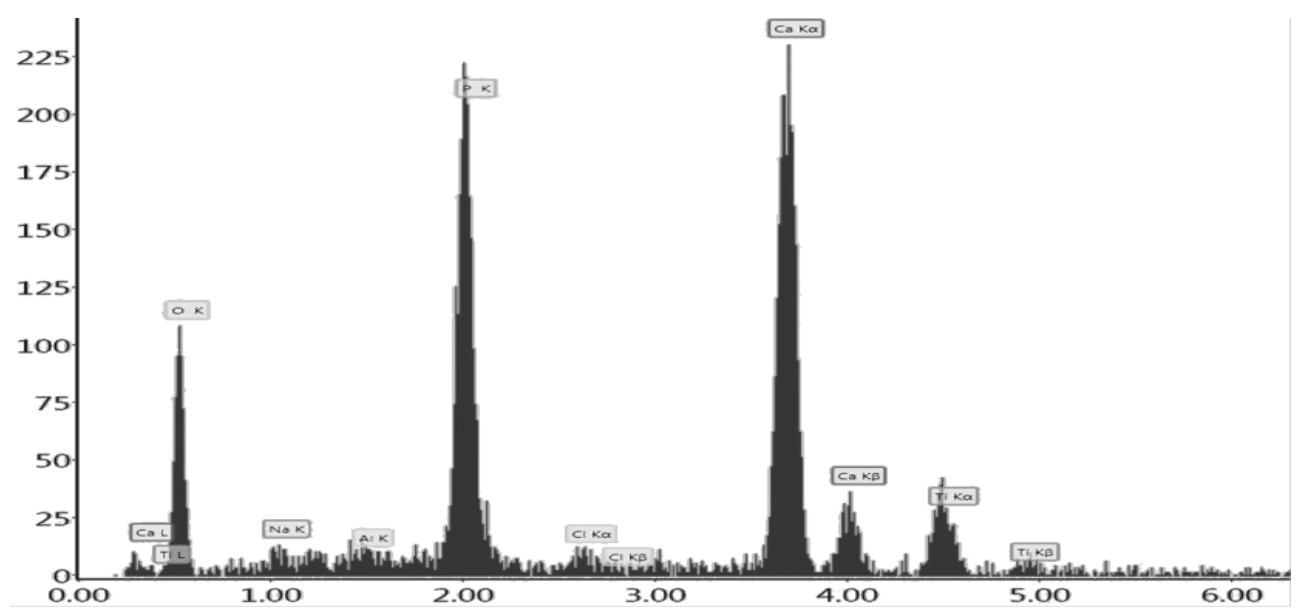

(a)

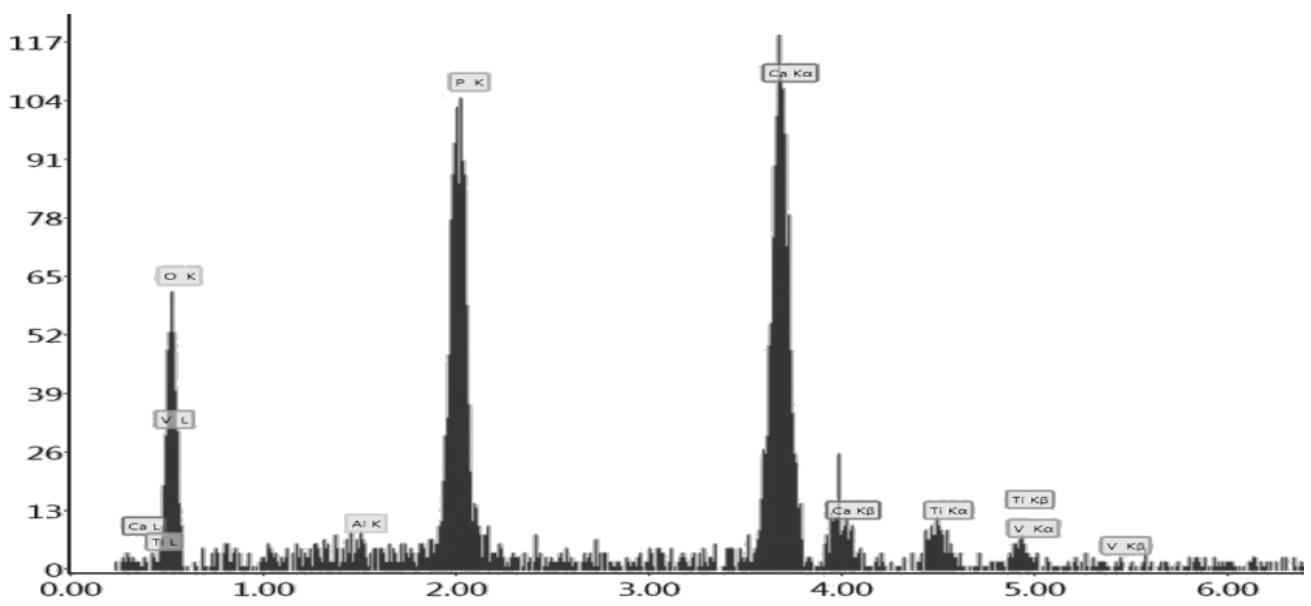

(b)

Figure 7. Comparison of EDX graphs for sample C (a) before sintering and (b) after sintering.

\section{$X$-ray diffraction}

Generally, the sintered component of HA/Ti is formed in the secondary phase [41-44]. Figures 8 to 10 show that the samples were converted into a new phase after sintering at $1200{ }^{\circ} \mathrm{C}$. The amount of titanium in the mixture affected the peak intensity [45], and HA decomposed and transformed into a secondary-phase substance, such as tetracalcium phosphate and tricalcium phosphate [46]. The presence of HA in the secondary phase wasevident not only under atmospheric conditions, but also in vacuum conditions [41]. After sintering, many peaks occurred in the pattern as an indication of the new phases that occurred after sintering. The XRD pattern showed that on the (70 wt $\%$ Ti6Al4V : $30 \mathrm{wt} \%$ HA: PMMA), the main HA peak remained. New peaks also occurred in the samples. Figure 8 shows that the HA phase decomposed and transformed into tetracalcium phosphate (TTCP) and beta tricalcium phosphate ( $\beta$-TCP). Egorov et al. showed that the oxidation of titanium started at around $700{ }^{\circ} \mathrm{C}$ on composite titanium and HA was converted into $\mathrm{TiO}_{2}[42]$. Figure 8 also shows that the sample (70 wt $\% \mathrm{Ti} 6 \mathrm{Al} 4 \mathrm{~V}: 30 \mathrm{wt} \%$ HA: PMMA) tended to exhibit a high level of oxidation, as demonstrated by the strong peak of $\mathrm{TiO}_{2}$ near $20{ }^{\circ} \mathrm{C}$ to $25{ }^{\circ} \mathrm{C}$. This strong peak occurred because of the titanium which was the main constituent in the mixture. Another peak that occurred in the specimen was $\mathrm{CaO}_{9} \mathrm{Ti}_{4}$, resulting from the reaction between titanium and $\mathrm{HA}$ at elevated temperatures. 


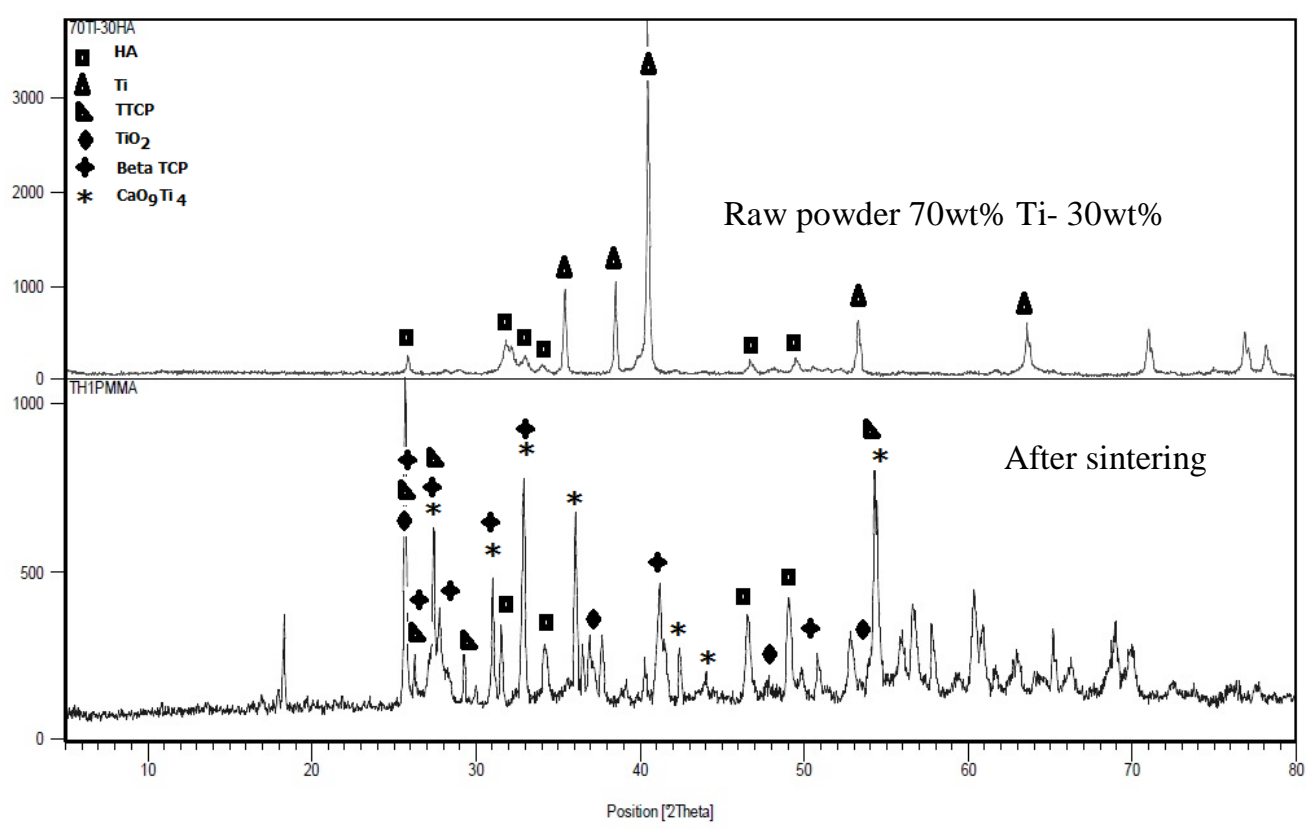

Figure 8. XRD pattern for sample A.

Figures 9 and 10 show that the main peak of HA disappeared in the XRD pattern, and HA was completely decomposed into $\beta$-TCP and TTCP. The main composition of $\mathrm{HA}(70 \mathrm{wt} \%)$ reduced in intensity. The $\mathrm{TiO}_{2}$ peak was an indication of reduced titanium oxidation. HA decomposition was a continuous process starting from low temperature and dehydroxylation process began at temperature $850{ }^{\circ} \mathrm{C}$ where $\mathrm{O}$ and $\mathrm{Ti}$ ions formed the $\mathrm{TiO}_{2}$ formation [46].

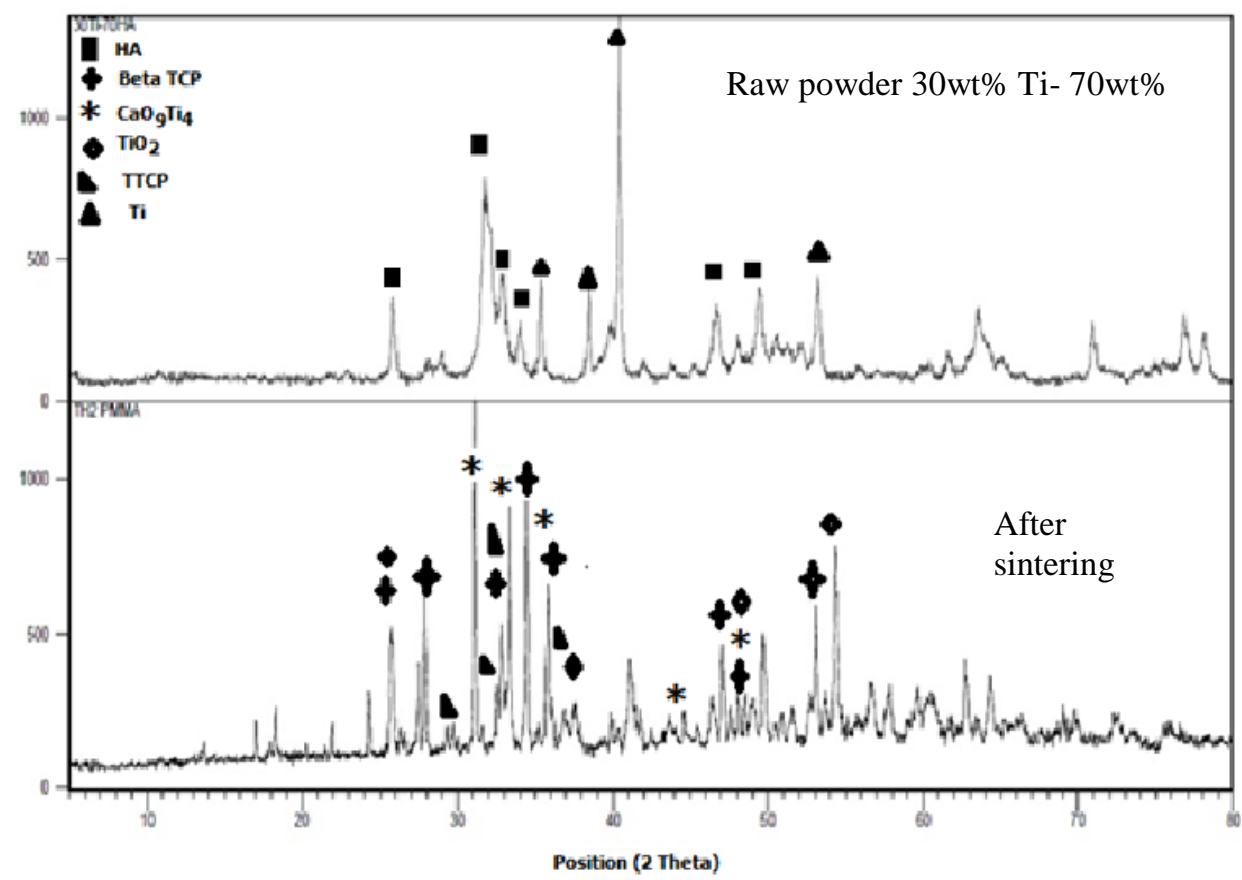

Figure 9. XRD pattern for sample B. 


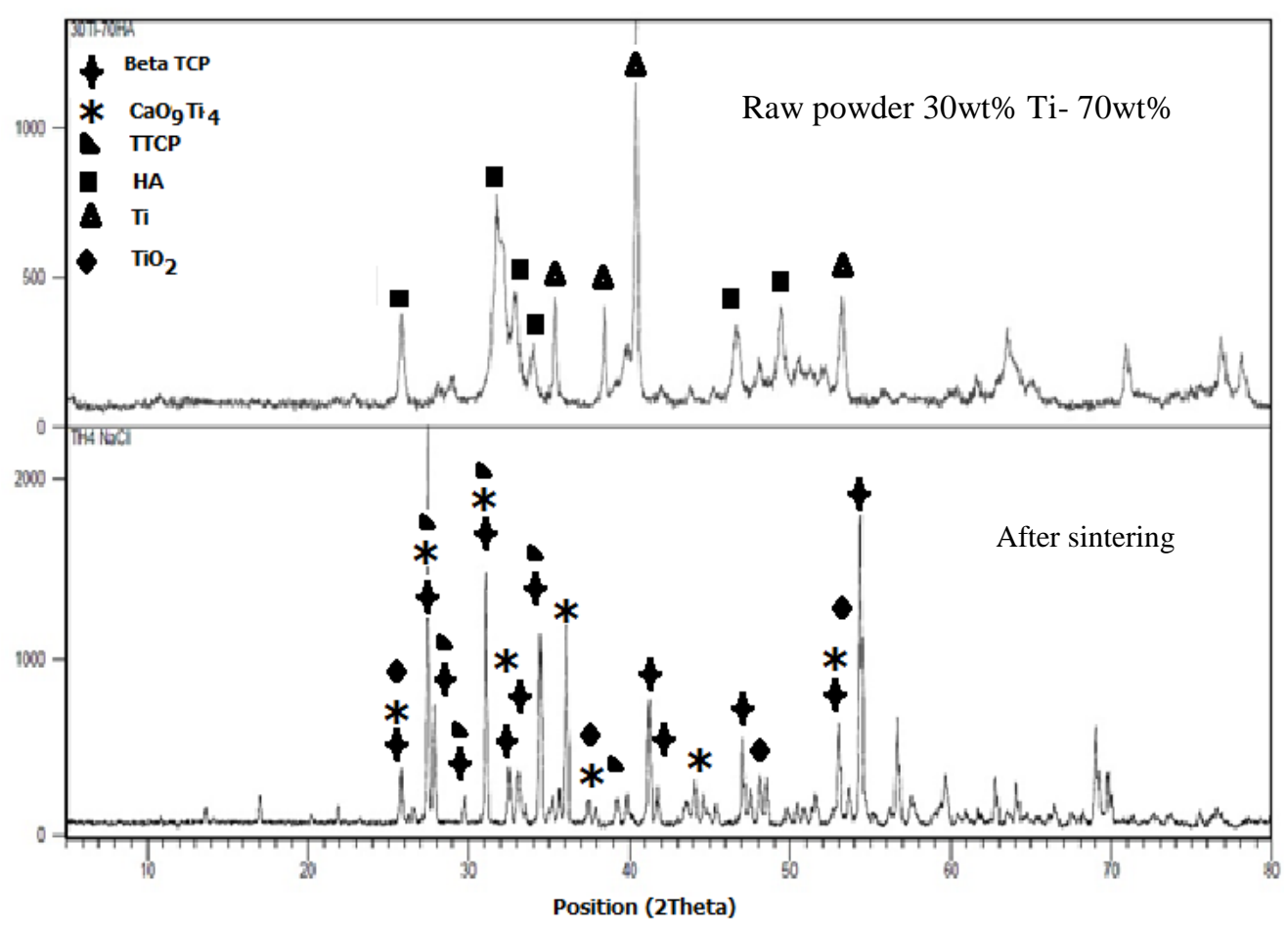

Figure 10. XRD pattern of sample C.

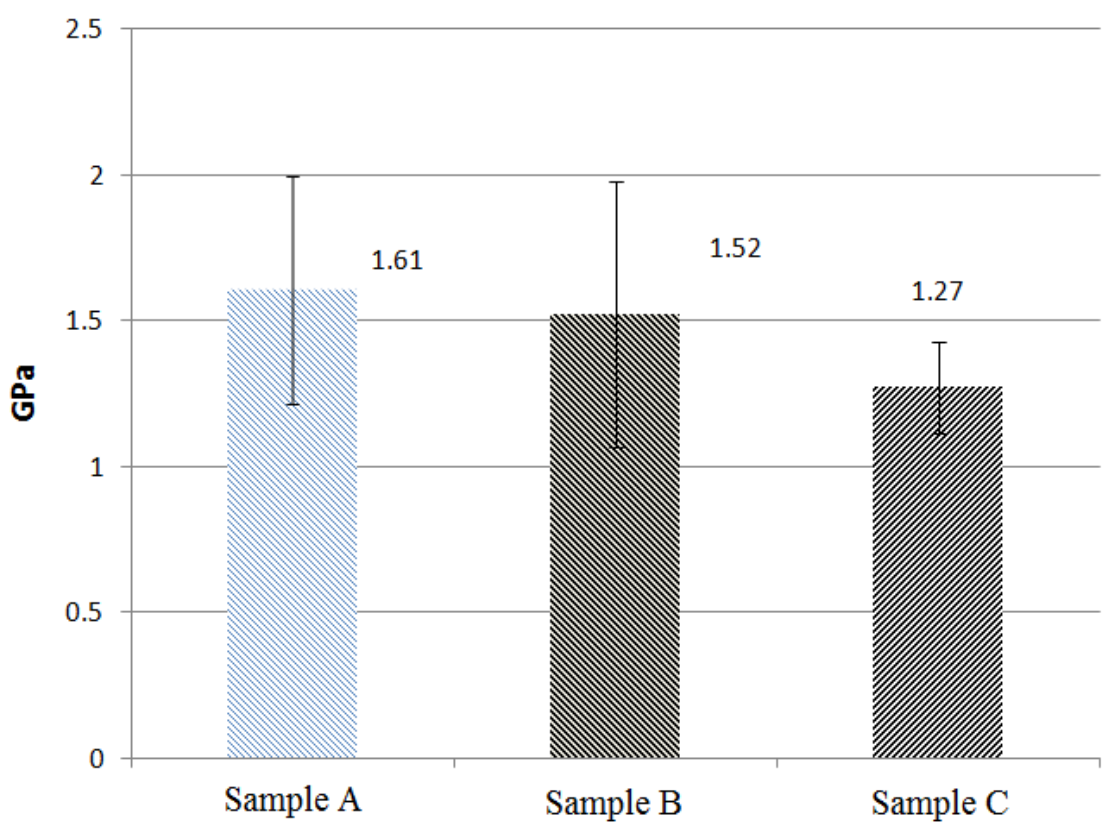

Figure 11. Hardness test results of porous Ti6Al4V/HA composite.

\section{Hardness test}

Figure 11 shows that the sample with titanium as the main constituent had a high hardness value. Sample $\mathrm{C}$ had a lower hardness value $(30 \mathrm{wt} \%$ ). This result is in a good agreement with Table 4, where high density material resulted high hardness and vice versa. Maximum hardness was obtained on sample A with a composition $70 \mathrm{wt} \%$ Ti6Al4V. The hardness result revealed that the debinding method had a contribution in influencing 
the morphology and percentage of porosity. Sample $\mathrm{C}$ had more porosity than samples A and $\mathrm{B}$; in this work, sample $\mathrm{C}$ was soaked in distilled water for $3 \mathrm{~h}$ to remove $\mathrm{NaCl}$. Sample C with $43.85 \%$ porosity attained a hardness value of $1.27 \mathrm{GPa}$, showing a potential application for bone implants where the average trabecular bone hardness is about $0.760 \mathrm{GPa}[13]$.

\section{CONCLUSIONS}

The experimental results showed that porous Ti6Al4V/HA composites were successfully fabricated using both types of space holders. Interconnected porous was clearly observed on the sintered composites with a size range of $2 \mu \mathrm{m}$ to $25 \mu \mathrm{m}$. Porosity is expected to facilitate the circulation of body fluids and encourage the growth of cells. Composition and powder shape of Ti6Al4V and HA played an important role in determining the formation and roughness of the structure. Moreover, the type of debinding method to remove the space holder from the green part has contributed to determining the microstructure porosity and morphology. Based on hardness test, composition $70 \mathrm{wt} \%$ Ti6Al4V with PMMA as the space holder (sample A) reached maximum hardness number, while the minimum hardness number was obtained by $30 \mathrm{wt} \%$ of Ti6Al4V using $\mathrm{NaCl}$ as the space holder. Samples with Ti6Al4V powder as the major component had a rough surface and large pore diameters. The pores in all the samples tended to interconnect three dimensionally, although controlling the pore size was difficult. The study results also demonstrated that HA decomposed into second-phase forms, such as TTCP and $\beta$-TCP. Other phases, such as $\mathrm{CaO}_{9} \mathrm{Ti}_{4}$ and $\mathrm{TiO}_{2}$, formed through the reaction of HA, titanium, and air.

\section{ACKNOWLEDGEMENTS}

This study was supported by Universiti Kebangsaan Malaysia's Research University Grant (grant no. UKM-DLP-2012-027) and the Malaysian Ministry of Higher Education (FRGS/1/2011/TK/UKM/02/20).

\section{REFERENCES}

[1] Liu J, Ruan J, Chang L, Yang H, Ruan W. Porous nb-ti-ta alloy scaffolds for bone tissue engineering: Fabrication, mechanical properties and in vitro/vivo biocompatibility. Mater Sci Eng C Mater Biol Appl. 2017;78:503-12.

[2] Shirtliff VJ, Hench LL. Bioactive materials for tissue engineering, regeneration and repair. Journal of Materials Science. 2003;38:4697-707.

[3] Mircheski I, Gradisar M. 3d finite element analysis of porous ti-based alloy prostheses. Comput Methods Biomech Biomed Engin. 2016;19:1531-40.

[4] Kanhed S, Awasthi S, Goel S, Pandey A, Sharma R, Upadhyaya A, et al. Porosity distribution affecting mechanical and biological behaviour of hydroxyapatite bioceramic composites. Ceramics International. 2017;43:10442-9.

[5] Kitashima T, Kawamura T. Prediction of oxidation behavior of near- $\alpha$ titanium alloys. Scripta Materialia. 2016;124:56-8.

[6] Meguid SA. Mechanics and mechanisms of toughening of advanced ceramics. Journal of Materials Processing Technology. 1996;56:978-89.

[7] Ravi BG, Chaim R, Gedanken A. Sintering of bimodal alumina powder mixtures with a nanocrystalline component. Nanostructured Materials. 1999;11:853-9. 
[8] Cui C, Hu B, Zhao L, Liu S. Titanium alloy production technology, market prospects and industry development. Materials \& Design. 2011;32:1684-91.

[9] Niinomi M. Recent research and development in titanium alloys for biomedical applications and healthcare goods. Science and Technology of Advanced Materials. 2003;4:445-54.

[10] Li Y, Munir KS, Lin J, Wen C. Titanium-niobium pentoxide composites for biomedical applications. Bioactive Materials. 2016;1:127-31.

[11] Hamdan SH, Md Said AY, Biki JR. Surface finish when threading titanium-based alloy under dry machining. Journal of Mechanical Engineering and Sciences. 2014;7:1062-9.

[12] Leyens C, Peters M. Titanium and titanium alloys: John Wiley \& Sons; 2006.

[13] Zysset PK, Edward Guo X, Edward Hoffler C, Moore KE, Goldstein SA. Elastic modulus and hardness of cortical and trabecular bone lamellae measured by nanoindentation in the human femur. Journal of Biomechanics. 1999;32:1005-12.

[14] Arifin A, Sulong AB, Muhamad N, Syarif J, Ramli MI. Material processing of hydroxyapatite and titanium alloy (ha/ti) composite as implant materials using powder metallurgy: A review. Materials \& Design. 2014;55:165-75.

[15] Sopyan I, Gunawan, Shah QH, Mel M. Fabrication and sintering behavior of zincdoped biphasic calcium phosphate bioceramics. Materials and Manufacturing Processes. 2015;31:713-8.

[16] Ryan G, Pandit A, Apatsidis DP. Fabrication methods of porous metals for use in orthopaedic applications. Biomaterials. 2006;27:2651-70.

[17] Vasconcellos LM, Leite DO, Nascimento FO, Vasconcellos LG, Graca ML, Carvalho YR, et al. Porous titanium for biomedical applications: An experimental study on rabbits. Medicina Oral Patologia Oral Y Cirugia Bucal. 2010:e407-e12.

[18] von Doernberg M-C, von Rechenberg B, Bohner M, Grünenfelder S, van Lenthe $\mathrm{GH}$, Müller R, et al. In vivo behavior of calcium phosphate scaffolds with four different pore sizes. Biomaterials. 2006;27:5186-98.

[19] Chang B-S, Lee iCKfC-K, Hong K-S, Youn H-J, Ryu H-S, Chung S-S, et al. Osteoconduction at porous hydroxyapatite with various pore configurations. Biomaterials. 2000;21:1291-8.

[20] Maleque MA, Radhi M, Rahman MM. Wear study of mg-sicp reinforcement aluminium metal matrix composite. Journal of Mechanical Engineering and Sciences. 2016;10:1758-64.

[21] Fajrin J, Zhuge Y, Bullen F, Wang H. Flexural behaviour of hybrid sandwich panel with natural fiber composites as the intermediate layer. Journal of Mechanical Engineering and Sciences. 2016;10:1968-83.

[22] Yusuf MYM, Selamat MZ, Sahari J, Daud MAM, Tahir MM, Hamdan HA. Fabrication of a flow channel for the production of polymer composite bipolar plates through hot compression molding. Journal of Mechanical Engineering and Sciences. 2017;14:2428-42.

[23] Khan MM, Dixit G. Erosive wear response of sicp reinforced aluminium based metal matrix composite: Effects of test environments. Journal of Mechanical Engineering and Sciences. 2017;14:2401-14.

[24] Haris A, Tay TE, Tan VBC. Experimental analysis of composite bolted joints using digital image correlation. Journal of Mechanical Engineering and Sciences. 2017;14:2443-55. 
[25] Kolawole MY, Aweda JO, Abdulkareem S. Archachatina marginata bio-shells as reinforcement material in metal matrix composites. International Journal of Automotive and Mechanical Engineering. 2017;14:4068-79.

[26] Ahmed S, Ahsan A, Hasan M. Physico-mechanical properties of coir and jute fibre reinforced hybrid polyethylene composites. International Journal of Automotive and Mechanical Engineering. 2017;14:3927-37.

[27] Jurczyk M, Jurczyk K, Niespodziana K. The manufacturing of titaniumhydroxyapatite nanocomposites for bone implant applications. Nanopages. 2006;1:219-29.

[28] Zhuravleva K, Chivu A, Teresiak A, Scudino S, Calin M, Schultz L, et al. Porous low modulus ti40nb compacts with electrodeposited hydroxyapatite coating for biomedical applications. Materials Science \& Engineering C-Materials for Biological Applications. 2013;33:2280-7.

[29] Niespodziana K, Jurczyk K, Jakubowicz J, Jurczyk M. Fabrication and properties of titanium-hydroxyapatite nanocomposites. Materials Chemistry and Physics. 2010;123:160-5.

[30] Nomura N, Sakamoto K, Takahashi K, Kato S, Abe Y, Doi H, et al. Fabrication and mechanical properties of porous ti/ha composites for bone fixation devices. Materials Transactions. 2010;51:1449-54.

[31] Torres Y, Pavón JJ, Rodríguez JA. Processing and characterization of porous titanium for implants by using nacl as space holder. Journal of Materials Processing Technology. 2012;212:1061-9.

[32] Baklouti S, Bouaziz J, Chartier T, Baumard JF. Binder burnout and evolution of the mechanical strength of dry-pressed ceramics containing poly(vinyl alcohol). Journal of the European Ceramic Society. 2001;21:1087-92.

[33] Belgacem M, Thierry B, Jean-Claude G. Investigations on thermal debinding process for fine 3161 stainless steel feedstocks and identification of kinetic parameters from coupling experiments and finite element simulations. Powder Technology. 2013;235:192-202.

[34] Khoong LE, Lam YC, Chai JC, Ma J, Jiang L. Modeling of mass transfers in a porous green compact with two-component binder during thermal debinding. Chemical Engineering Science. 2009;64:2837-50.

[35] Shengjie Y, Lam YC, Chai JC, Tam KC. Simulation of thermal debinding: Effects of mass transport on equivalent stress. Computational Materials Science. 2004;30:496-503.

[36] Mansourighasri A, Muhamad N, Sulong AB. Processing titanium foams using tapioca starch as a space holder. Journal of Materials Processing Technology. 2012;212:83-9.

[37] Torres Y, Pavon JJ, Rodriguez JA. Processing and characterization of porous titanium for implants by using nacl as space holder. Journal of Materials Processing Technology. 2012;212:1061-9.

[38] Shahzeydi MH, Parvanian AM, Panjepour M. The distribution and mechanism of pore formation in copper foams fabricated by lost carbonate sintering method. Materials characterization. 2016;111:21-30.

[39] Lu JX, Flautre B, Anselme K, Hardouin P, Gallur A, Descamps M, et al. Role of interconnections in porous bioceramics on bone recolonization in vitro and in vivo. Journal of Materials Science: Materials in Medicine. 1999;10:111-20.

[40] Ye H, Liu XY, Hong H. Characterization of sintered titanium/hydroxyapatite biocomposite using ftir spectroscopy. J Mater Sci Mater Med. 2009;20:843-50. 
[41] Yang Y, Kim K-H, Agrawal CM, Ong JL. Interaction of hydroxyapatite-titanium at elevated temperature in vacuum environment. Biomaterials. 2004;25:2927-32.

[42] Egorov A, Smirnov V, Shvorneva L, Kutsev S, Barinov S. High-temperature hydroxyapatite-titanium interaction. Inorganic Materials. 2010;46:168-71.

[43] Berezhnaya A, Mittova V, Kostyuchenko A, Mittova I. Solid-phase interaction in the hydroxyapatite/titanium heterostructures upon high-temperature annealing in air and argon. Inorganic Materials. 2008;44:1214-7.

[44] Gunawan, Sopyan I, Nurfaezah S, 'Ammar M. Development of triphasic calcium phosphate-carbon nanotubes (ha/tcp-cnt) composite: A preliminary study. Key Engineering Materials. 2012;531-532:258-61.

[45] Salman S, Gunduz O, Yilmaz S, Öveçoğlu ML, Snyder RL, Agathopoulos S, et al. Sintering effect on mechanical properties of composites of natural hydroxyapatites and titanium. Ceramics International 2009;35:2965-71.

[46] Tõnsuaadu K, Gross KA, Plūduma L, Veiderma M. A review on the thermal stability of calcium apatites. Journal of Thermal Analysis and Calorimetry. 2011;110:647-59. 